\title{
MAP/Microtubule Affinity-Regulating Kinase 4
}

National Cancer Institute

\section{Source}

National Cancer Institute. MAP/Microtubule Affinity-Regulating Kinase 4. NCI Thesaurus.

Code C114393.

MAP/microtubule affinity-regulating kinase 4 (752 aa, $83 \mathrm{kDa}$ ) is encoded by the human MARK4 gene. This protein plays a role in microtubule-associated protein phosphorylation. 